\title{
Israeli High School Graduates' Knowledge of the Holocaust: A Case Study
}

\author{
Nitza Davidovitch, Amir Haskel, Esther Wagner, Shaked Jacobson-Meyzles, Liraz Bahamam \\ Ariel University
}

In November 2015, the Israeli Ministry of Education declared that the matriculation exam in history would no longer include the Holocaust, and instead students would be required to write a research paper. Following this decision, we wished to test the level of knowledge concerning the Holocaust among undergraduate students (excluding those who study contemporary history, which includes Holocaust studies). For this purpose, 145 participants were sampled, students at four Israeli academic institutions: two universities and two colleges. The research question referred to remembering information about the Holocaust and the study took into account students' different personal, family, and academic background (having participated in the journey to Poland or not, having relatives who had died or survived the Holocaust, being religious or secular). The knowledge survey refers to terms from four areas: people, historical events during the Holocaust era, organizations that operated in that period, and places and methods of killing. In general, the level of knowledge was found to be very low (general knowledge score: 42.6 of 100). No significant differences were found in scores by religion or participation in the journey to Poland, aside from knowledge about places and methods of killing, where we found a significant difference between those who participated in the journey to Poland and those who did not. In addition, no significant differences were found between participants whose relatives had died in or had survived the Holocaust, or by either the number of years since high school graduation or gender. From the respondents' answers, it appears that high school studies play an essential role as the main perceived source of knowledge $(90.4 \%$ referred to school as a main or additional knowledge source). When asked about the new exam format, the majority (52.1\%) replied that they would prefer writing a research paper to taking an exam. The low level of knowledge that we found raises practical questions: Are the schools teaching correctly? Should the study program be reviewed? Are we providing the right highlights? What is the contribution of the journey to Poland if $60 \%$ of the participants are not familiar, for example, with Mordechai Anielewicz? What can be done to improve the situation? Will the decision to exclude Holocaust topics from the high school finals in history and to require students to write a research paper, improve the situation? What is the future of remembrance in a generation that will have no Holocaust survivors to tell their personal story? It is necessary to check the importance of the school as a primary source of knowledge and how to improve the study methods so that the knowledge will be preserved. Perhaps the informal teaching that includes the journey to Poland plays an important role and should be used more often. Furthermore, despite students' support of the reform and the conception that writing a research paper is better than taking an exam about the Holocaust, there is a need to check what is included in this research paper and whether writing it on a specific subject connected to

Nitza Davidovitch, Prof., Department of Social Studies, Ariel University, Israel; main research fields: Studies on Higher Education, Promotion of Academic Instruction, and Performance Measures in Higher Education, Development of Unique Assessment Studies, and Research Resource Development.

All authors: Department of Social Studies, Ariel University. 
the Holocaust won't cause a situation where the students are only proficient in that subject with regard to the Holocaust. In addition, the student's ability to prepare a research paper should be considered. Indeed, the students replied that they would be capable of writing such a paper, but the question is whether high school students indeed have the necessary proficiency and tools.

Keywords: Holocaust, undergraduate students, knowledge, Israel, high school graduates

\section{The School System and Holocaust Studies}

Only in 1981 did the Knesset accept the amendment to the State Education Law of 1953, which determined the obligation to include Holocaust studies in the school system's formal curriculum. When examining the centrality of the Holocaust as a topic within Israel's history, from the establishment of the state until this amendment to the law, three stages may be discerned as leading towards this amendment. The first stage is from the state's initiation until establishment of Yad Vashem in 1953. The second stage ended in 1960, with the capture of Adolf Eichmann. The third stage was until the Six Day War. The fourth stage was until the Yom Kippur War, and the fifth stage continued until the amendment to the State Education Law.

The first two stages were characterized by two conflicting trends: on one hand, the need to remember the Holocaust, with an emphasis on bravery. This need was manifested in legislation and in the establishment of commemoration institutions. These efforts were counterbalanced by the survivors' wish to return to a normal life cycle and to become integrated in Israeli society. For this purpose, they sought to repress and forget the dark era. At the same time, the newly founded state was also coping with no less significant challenges to its immediate existence, such as security problems, immigration absorption, and forming an economic infrastructure.

In Israel's first decade, the school system focused on teaching the young generation the story of efforts to establish the state. These efforts included activities of the various underground movements against the British Mandate, the struggle against the Arabs, and the IDF's bravery in the War of Independence. A contrast was formed between the success of the "new Jew" and the failure of the exilic Jew, as manifested in going "as sheep to the slaughter." For this reason, the formal school system did not mention the story of the Holocaust, aside from emphasizing the Nazis' atrocities and the bravery of the Jewish ghetto fighters and partisans. The fighting in the ghettos and in the forests received even more of an emphasis in the informal educational system and kibbutz youth movements.

Yad Vashem was established in 1953. At first, the management worked to put together a library, archives, and commemoration buildings. Yad Vashem researchers dealt mainly with collecting archival material, while the educational task, one of the institution's main declared goals, received second priority. In those years, the formal school system was engaged in deepening students' Jewish affiliation and knowledge of Jewish history. Holocaust studies, in contrast, were deficient.

The capture of Adolf Eichmann and his trial were the first to expose the terrible disaster in Europe to all parts of the Israeli public. Dozens of Holocaust survivors related their shocking stories on the witness stand. The concentrated and intensive journalistic coverage of the trial also helped expose Israelis to the complex and inconceivable events that occurred on European soil during World War II. Faced with the picture reflected by the testimonies in the Eichmann Trial, some educators and researchers sought to present a more balanced picture of the Holocaust. However, these attempts were not welcomed. The misery of the survivors only served 
to increase the arrogance of young Israelis. The latter had been taught about the strength and bravery of the IDF and the mythos of the few versus the many. Their denigrating attitude towards Diaspora Jews only grew. Questions that arose during the trial concerning Holocaust studies were rejected and the conviction that the Holocaust should be studied in the vicinity of Holocaust and Heroism Remembrance Day rather than in a distinct academic setting became even further entrenched.

The period of waiting and existential anxiety on the eve of the Six Day War once again raised public awareness of the Holocaust, but not for long. The ringing victory proved that an independent country and a strong army are the only response to Jewish life in the Diaspora. At this stage, Yad Vashem served, among other things, as a "showcase" for world leaders and politicians, demonstrating the disaster that had befallen the Jewish people when in exile.

Despite the awakening generated by the Six Day War, the genocide in Biafra and Bangladesh, developments in historical research, and the literature that had begun to emerge concerning the Holocaust - the school system still adhered to the opinion that the Holocaust should only be dealt with in the vicinity of Remembrance Day. The commemoration institutions established over the years served as an alternative to systematic and thorough study of the topic. Most students continued to visit Yad Vashem and the Ghetto Fighters' Museum only on annual school trips.

The trauma caused by the first days of the Yom Kippur War was a strong contrast to the euphoria in which the Six Day War had ended. Where in Israel's first years Israelis suffered from existential anxiety, the Six Day War freed them from this anxiety. The oversights of the Yom Kippur War and the heavy price paid by Israeli society had the effect of undermining the sense of existential security.

In the 1970s, neo-Nazi and Holocaust denial organizations began to emerge throughout the world. As a result of Israel's political transformation in 1977 and its political isolation since the Yom Kippur War, attempts were made to utilize the Holocaust in political arguments, both internally and on the global stage. Public figures and members of Knesset stressed their personal association with the Holocaust. Political use of the Holocaust's lessons became common. The media as well reinstated the Holocaust on the national agenda, affecting public opinion.

In the current state of affairs, pressure was brought to bear on the school system, both by Holocaust researchers and by Holocaust survivors. All these demanded that the system changed its policy. The media as well began to express interest in Holocaust studies within the school system. In the field, teachers initiated independent study programs on the subject and also sought the approval of the Ministry of Education to incorporate them in the curriculum. Holocaust survivors brought pressure to bear in the Knesset through their representatives. Hence, a decision was reached to form compulsory Holocaust studies in elementary schools (Amendment to the State Education Law of 1953).

In conclusion, in the 1950s, the Israeli school system referred only minimally to the Holocaust, both in the curriculum and in ceremonial activities on Holocaust Remembrance Day. Dr. Gabi Ofir wrote the following in an article published in 1959 in Yad Vashem News: "It is enough to inquire among several graduates of elementary and high schools in order to understand that, with a few exceptions, they lack elementary knowledge of the Holocaust... The teachers themselves are to blame, as in most cases they do not take the time to acquire essential knowledge that can then be imparted to the students" (Balf 2011, 83). In other words, one of the problems was that the teachers themselves were not proficient in facts and information concerning the Holocaust era. 
Another study published in 1960 found that about one quarter of educational institutions ignored the Holocaust completely. Many schools did not include the Holocaust in their curriculum and those that did give it a marginal place. Prof. Hanna Yablonka, in her review of the state school system's work on the eve of the Eichmann Trial, described the situation:

It is, therefore, the impression that the Ministry of Education and Culture sees itself obligated to deal with the Holocaust [in the 1950s] only as required by law, and therefore all mention of the Holocaust in the formal school system, as instructed by the ministry, was associated only with Remembrance Day, as decreed by the Yad Vashem Law, or by the Holocaust and Heroism Remembrance Day Law, enacted by the Knesset in the early1950s. (Balf 2011, 83)

Prof. Ben-Zion Dinur (Dinaburg), then the Minister of Education, who was the motivating force behind the Yad Vashem Law, resigned in 1955. In his absence, the Ministry of Education ceased almost all references to the Holocaust. This situation continued for a long time. Only in 1979 was instruction of the Holocaust accepted as an official part of the curriculum, and as stated, only in 1981 was a study unit on the Holocaust included as mandatory study material for the matriculation exams.

\section{Differences between the Various Educational Streams}

Aside from the method of study, there appear to be differences in studies in general and in studies of the Holocaust in particular between state schools and state religious schools. The State Education Law is considered a significant junction in the history of Jewish education in Israel. The declared purpose of the law was to transfer the schools from the control of sectorial organizations to the centralized control of the state. It was an attempt to cope with the multiple streams and cultures by unifying them, both organizationally and ideologically. The law was originally only supposed to include one stream that of the state school system, with no separate religious school system, but due to strong objections by the religious parties a compromise was found, involving separation of the general and religious streams. As a result, over time, an impression was formed whereby studying Jewish values and imparting a Jewish consciousness are the exclusive functions of the state religious school system (Davidovitch \& Soen 2015b). The study program of the state school system primarily emphasizes the Zionist-national and universal dimension, and eleventh graders study about World War II in general, and specifically about the "Final Solution," referring to the comprehensive Nazi plan to solve the Jewish problem by murdering all European Jews. Interestingly, in most state curricula dealing with instruction of the Holocaust, religious life has no place or is mentioned only sporadically. In the religious sector, in contrast, ninth graders study a chapter on the Holocaust from the Jewish, private, individual aspect (Davidovitch 2015).

\section{Experiential Learning and the Journey to Poland}

The study process does not end with academic studies, which have developed over the years, rather it further developed and grew in other directions, including studying about the Holocaust in informal settings. Informal studies involve experiential learning, which is divided in two: learning experienced by one in daily life and from one's life experience and learning through programs planned by others. In addition, experiential learning is an educational method with pros and cons. Within Holocaust studies, school trips to Poland, from Israel and elsewhere, are one of the major experiential study programs. Israel's school system seeks, among other things, to instill values in the students. Value education is usually carried out by nurturing the individual's sensitivities to values, imparting tools that assist in making ethical decisions, and creating learning experiences 
from which one learns about the sensitivities of others (Davidovitch \& Soen 2015a). The purpose of the trips appears to be to connect the students with the world of death, as a consequence of which they will learn to appreciate their own country, Israel, as a source of life and a destination for immigration. Nevertheless, some critics have claimed that preparations for the trip and the outlining of its aims are not sufficiently thorough and that the trip, despite its intensity, does not lead to desirable results because some of the problems it raises do not meet with proper treatment (Davidovitch \& Soen 2011).

In Holocaust studies in general and in the journey to Poland in particular, we see an attempt to use experiential learning as a way of imparting ethical goals, where Israel's school system sees itself obligated to impart to students the full Jewish and human historical, moral, and educational significance of Jewish fate. The journey is intended to enhance the students' belonging to the people of Israel and their affiliation with the Jewish heritage and history. The journey to Poland constitutes a type of adventure program, utilized in order to generate learning. The journey is considered a unique experiential learning method lasting eight intensive days, in which students visit former Jewish centers, extermination sites, and Polish tourist sites. The visit includes exposure to strong emotional experiences, to Nazi atrocities, and to the rich culture of Eastern European Jews. The Ministry of Education is in charge of the methodical dimension of the journeys to Poland. The ministry is responsible for the contents to which the students are exposed before, during, and after the journey. Beginning from 1988, Director General Circulars have explicitly defined the experiential learning contents encompassed by the journey to Poland. For example, the ministry predetermines the list of institutions recognized by the Society and Youth Administration as dealing with Holocaust research and study for the purpose of preparing youth delegations to Poland (Davidovich \& Soen 2015a). Furthermore, it appears that the journeys to Poland have constituted a means of imparting certain world views. They were considered an obvious part of the educational reality in Israel. After 20 years, students' trip to Poland may be said to have become rooted and even become a type of "initiation ceremony" for teens, as the journey to Poland is mostly characteristic of teenagers and high school students (Davidovitch \& Soen 2011). Aside from the journeys to Poland, there are other types of informal learning. According to Davidovitch and Soen (2015a), in Israel's six decades, many Holocaust museums and institutes have been established, with the goal of shaping remembrance of the Holocaust within Israeli society. The most conspicuous are the Holocaust Basement, Yad Vashem, the Itzhak Katzenelson Ghetto Fighters House, Masuah, Beit Ha'Edut, the Diaspora Museum, and Moreshet. The museums enable another type of experiential learning and they are also in charge of instilling educational, experiential, and cognitive challenges. But regretfully, a glance at the databases of visitors to institutes of Holocaust studies shows that only a small percentage of students who visit come as part of the school program for Holocaust studies. This, aside from the visit to Yad Vashem, which constitutes an integral part of the high school curriculum and has even become a type of symbol within Israeli society, recognized as it is as the most well-known Holocaust museum.

\section{The Reform}

Due to the significance of the issues mentioned above concerning Holocaust studies and the structuring of learning over the years, whether differences between the state religious and state school systems, or between formal and informal learning, a shift appears to have occurred in Holocaust studies in the schools. The transformation is manifested mainly in the elimination of the Holocaust as a topic studied for the matriculation exams, instead of which students will be required to write a research paper on the subject. According to the 
"Israel Advances" program led by Minister of Education Naftali Bennett, the significance lies in developing thinking, creativity, and self-study skills as a major goal. The Holocaust as a topic, formerly part of the material studied for the matriculation exam in history, which as part of the reform is being removed from the exam in favor of self-study and writing a research paper, is arousing outrage among many teachers and educators. According to the new program, eleventh graders, who were previously tested on the Holocaust in the matriculation exam, will study about this topic and write a research paper on which they will receive an alternative school-based evaluation (http://www.nrg.co.il/online/1/ART2/735/464.html).

\section{Research Rationale}

As stated, in November 2015, the Ministry of Education announced a new reform, whereby the Holocaust would no longer be part of the matriculation exam in history, and instead of a test students will be required to write a research paper. Following the decision, we sought to examine the level of knowledge about the Holocaust among undergraduate students (excluding students of contemporary history who study about the Holocaust). The research respondents are undergraduate students who graduated from high school several years ago. We will attempt to inquire how much knowledge about the Holocaust the students retained, and we will also examine the major source of knowledge, whether the knowledge received and retained is mainly formal, obtained at school in general and from studies for the matriculation exam in particular, or informal, generated by the journey to Poland or other informal settings. Differences between the religious and secular school systems regarding Holocaust studies will be explored. Furthermore, we will attempt to inquire whether the years that passed since the students graduated from high school are meaningful, and whether students who feel an affinity with this topic, due to a relative who was a victim or survivor of the Holocaust, will have stronger memories. We hypothesize that differences will be found between the knowledge of those who participated in the journey and of those who did not, and that differences will be found between the knowledge of students who are related to someone who was a victim or survivor of the Holocaust and of those who are not.

\section{Method}

\subsection{Research Population}

The research participants included 145 respondents (107 women and 38 men) aged 19-31. Participants' mean age was 24. The respondents were students at two universities (the Technion and Ariel) and two colleges (the Oranim College and the Sapir College). Thirty eight percent defined themselves as religious, $30 \%$ as traditional, and $32 \%$ as secular. Forty four percent had participated in the journey to Poland (58 in high school, 4 in different settings, and one both in high school and in the army). Ninety four percent of the respondents reported visiting a Holocaust institute, and only $6 \%$ had not visited any institute. Of all respondents, $46.5 \%$ reported some family association with victims or survivors of the Holocaust.

Figure 1 shows that $46 \%$ of the respondents reported having acquired their knowledge about the Holocaust at school, another $46 \%$ acquired their knowledge about the Holocaust at school combined with other places, and only $8 \%$ did not enumerate school among their knowledge sources. 


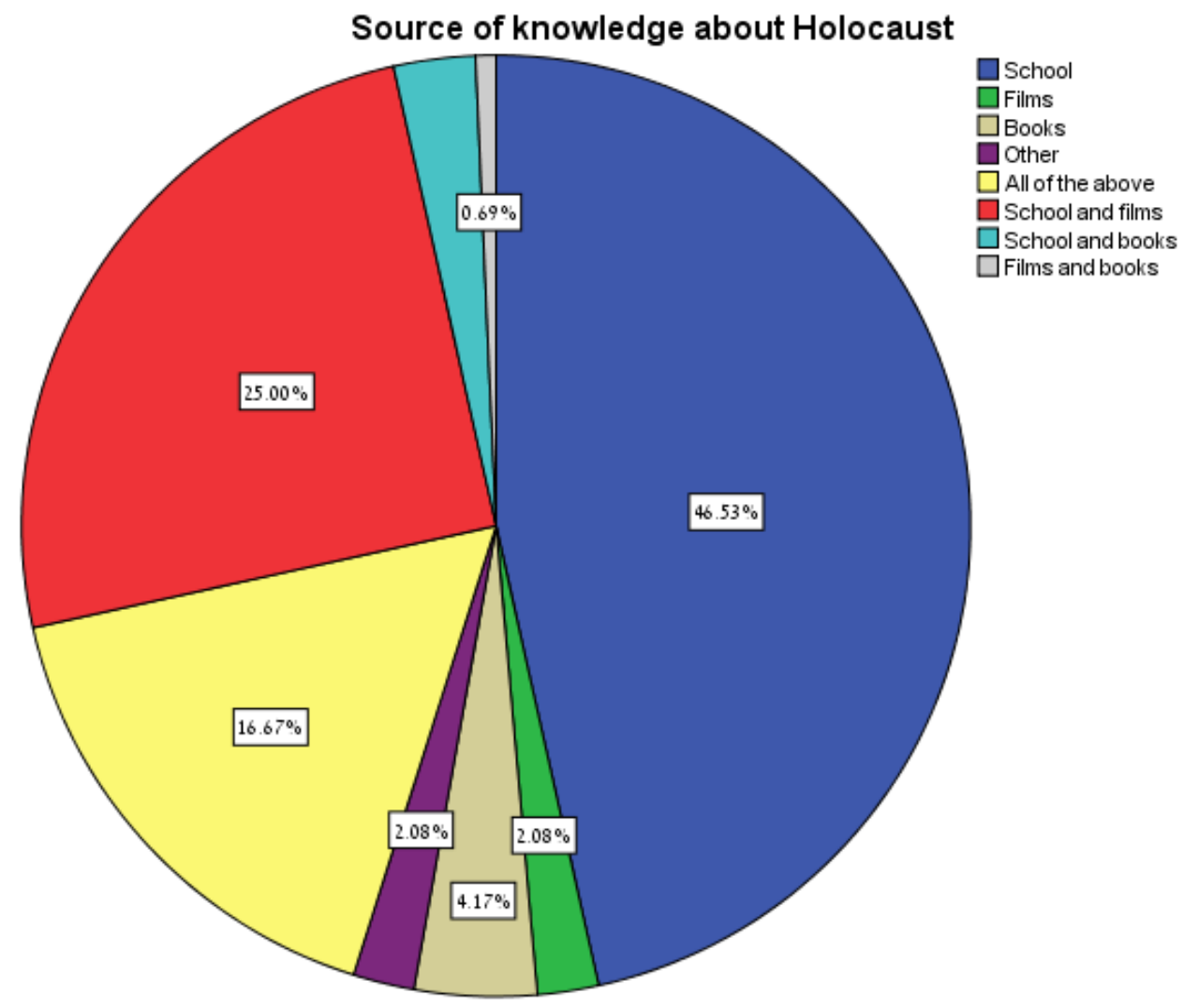

Fig. 1. Source of knowledge about the Holocaust.

\subsection{Research Tools}

Knowledge questionnaire about the Holocaust: The questionnaire was constructed specifically for this study by Amir Haskel, who serves as a guide for journeys to Poland, and by Prof. Nitza Davidovitch. The terms were selected based on four main categories: people, historical events, places and methods of killing, and organizations. The research questionnaire included 20 basic terms related to the Holocaust. The terms were selected from a list of names and terms in the book Holocaust and Remembrance, a high school textbook about the Holocaust written by Prof. Israel Gutman. In addition, several academics who specialize in this topic, high school history teachers, and Poland guides, provided feedback on the terms chosen.

The students were requested to write up to two lines about each term. The questionnaire ended with three closed questions, in which respondents were asked to state their sources of knowledge about the Holocaust, their attitude to the reform, and their personal preference for a test or writing a paper. The researchers reviewed the participants' replies and gave five points for each correct answer and zero point for each incorrect or partial answer. In order to examine the hypotheses, the scores were calculated as the percentage of correct answers of all questions. In addition, a score was calculated for each subcategory of questions (people, historical events, places and methods of killing, and organizations). Here too, the score reflects the percentage of each respondent's correct answers. Table 1 shows the distribution of scores among all research participants. 
Table 1

Scores on the Knowledge Test, $n=145$

\begin{tabular}{lllll}
\hline & Mean & Standard deviation & Minimum & Maximum \\
\hline General knowledge score & 42.6 & 18.5 & 0 & 100 \\
Score for knowledge about people & 23.2 & 27.6 & 0 & 100 \\
Score for knowledge about historical events & 40.4 & 20.6 & 0 & 100 \\
Score for knowledge about places and methods of killing & 64.4 & 23.9 & 0 & 100 \\
Score for knowledge about organizations & 30.9 & 21.5 & 0 & 100 \\
\hline
\end{tabular}

The second part included three closed questions that examined students' opinion on the reform:

- What is their main source of information about the Holocaust?

- Would they prefer to be tested or to write a paper on the Holocaust?

- Do they feel that they could have written a research paper in high school?

\subsection{Research Procedure}

The study was conducted from December 2015 to April 2016. Questionnaires were distributed to graduates of the Israeli high school system at two universities (the Technion and Ariel) and two colleges (the Oranim College and the Sapir College). One hundred and forty five questionnaires were completed by 107 women and 38 men aged 19-31.

Two researchers reviewed all the surveys to examine the answers to the open-ended questions. Each correct answer was given 5 points. A respondent who answered all 20 terms correctly received a score of 100 . No points were given for a partial answer.

\subsection{Research Findings}

Participation in the journey to Poland: A t-test for independent samples was conducted to check whether participation in the journey to Poland has an effect on the knowledge score. Statistically, the average scored of those who participated in the journey $(\mathrm{M}=46.65, \mathrm{SD}=18.08)$ were indeed found to be higher than of those who did not participate in the journey $(\mathrm{M}=39.75, \mathrm{SD}=18.52)(\mathrm{t}(143)=2.29, \mathrm{p}<0.05)$, but in both cases the score was "failed."

Figure 2 shows the distribution of scores between those who participated in the journey to Poland and those who did not participate in the journey to Poland. 


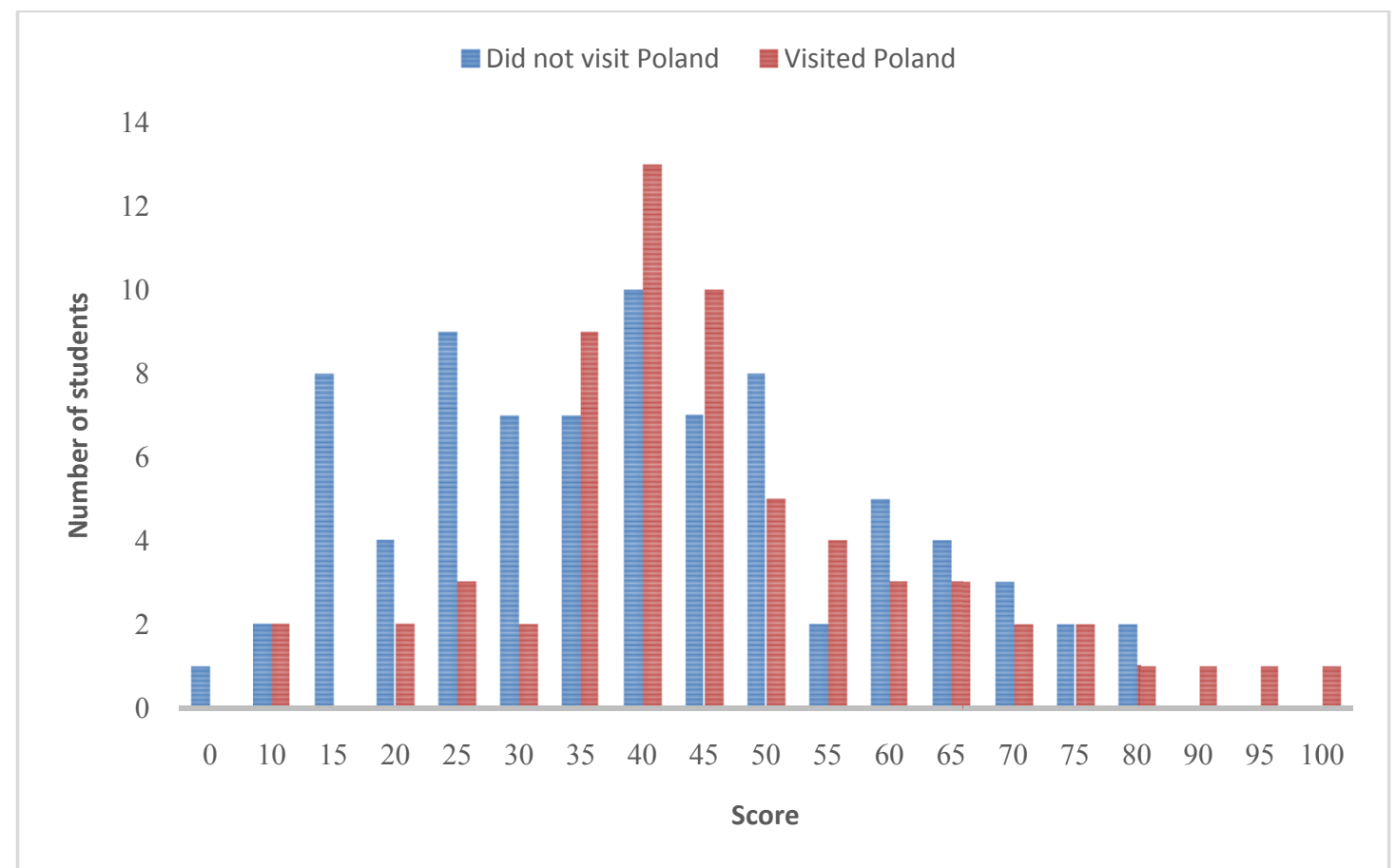

Fig. 2. Distribution of scores, separately for journey participants and for those who did not participate in the journey.

We shall examine the knowledge scores of those who participated in the journey to Poland versus those who did not, by the four categories of questions asked.

Figure 3 shows that only on questions regarding "places and methods of killing" was there a statistically significant difference between participants $(\mathrm{M}=71.6, \mathrm{SD}=19.4)$ and those who did not participate in the journey $(\mathrm{M}=58.6, \mathrm{SD}=25.56)(\mathrm{t}(143)=3.48, \mathrm{p}<0.01)$.

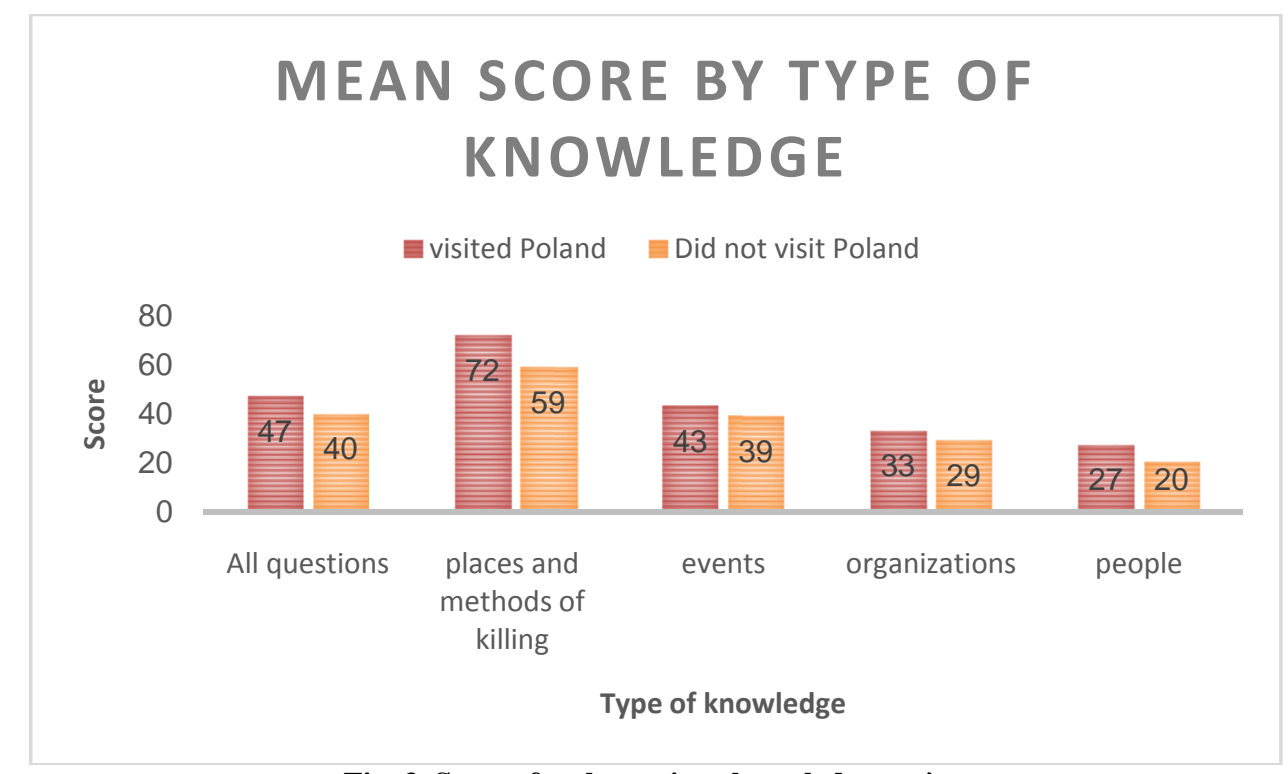

Fig. 3. Scores for the various knowledge topics.

Religiosity: In order to examine differences in scores by religiosity, a one-way analysis of variance was conducted. A difference was found $(\mathrm{F}(2,142)=8.17, \mathrm{p}<0.001)$, and a Scheffe post-hoc test showed that the mean 
score of the 55 respondents who defined themselves as religious $(M=49.82, S D=20.61)$ was significant higher than the mean score of the 44 respondents who defined themselves as traditional $(\mathrm{M}=35.57, \mathrm{SD}=15.78)$. No significant difference was found between the scores of these groups and the mean score of the 46 participants who defined themselves as secular $(\mathrm{M}=41.19, \mathrm{SD}=15.57)$. In all groups, notwithstanding the differences, the score was "failed."

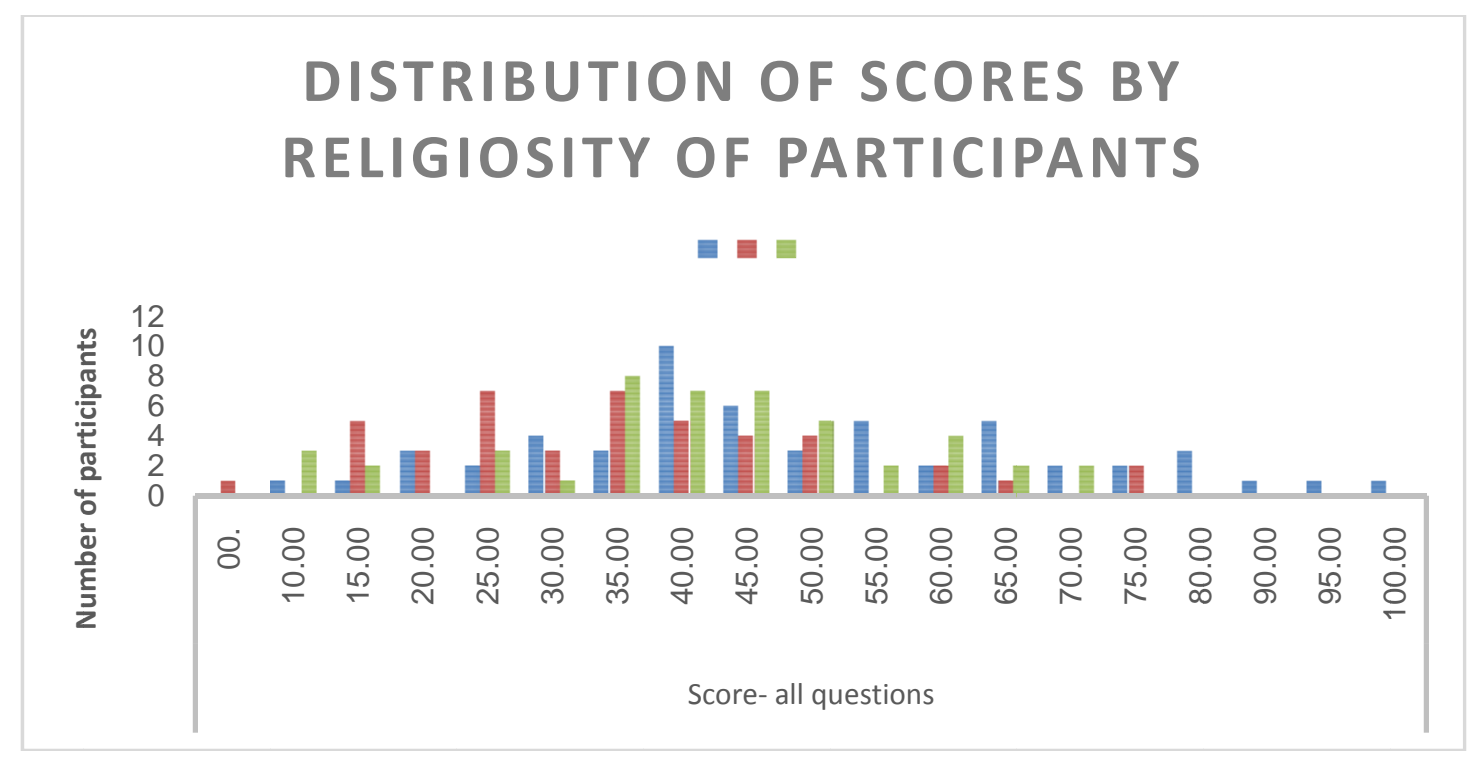

The hypothesis of an interaction between religiosity and participation in the journey to Poland and between the knowledge score, was examined by a two-way analysis of variance. No joint effect was found of participation in the journey and religiosity on the score $(p>0.05)$.

Types of knowledge: The hypothesis of a difference in scores by the various types of knowledge was also examined. The results of an analysis of variance found that there is indeed a significant difference between the scores for the various topics $(\mathrm{F}(3,402)=174, \mathrm{p}<0.001)$. A Bonferroni post hoc test found a significant difference between the scores for the different types of knowledge. The mean scores for each group of questions are presented in the table above (see Table 1) and in Figure 3.

No correlation was found between personal background in the following realms and knowledge:

Gender: In order to check for differences in the general score means of men and women, a t-test for independent samples was used and no significant difference was found between the groups $(\mathrm{p}>0.05)$.

Association with Holocaust survivors: In order to check for differences in the general score means of participants who attested to family ties with Holocaust victims or survivors, a t-test for independent samples was used, and no significant difference was found between the groups ( $p>0.05$ ).

Schooling and number of years since high school: The effect of schooling and of visits to a Holocaust institute on knowledge was examined. These variables were not found to be relevant, as $92 \%$ of respondents had visited a Holocaust institute. Moreover, no association was found between the number of years since high school and the various knowledge scores $(\mathrm{p}>0.05)$.

School as a source of knowledge: A mean score of 43 of 100 on the knowledge test on the Holocaust shows that students who learned about the Holocaust in the Israeli school system retained a small amount of knowledge. The study did not indicate that those who participated in the journey to Poland had more 
knowledge than those who did not, aside from the score for knowledge about places and methods of killing, which was 64.4.

With regard to the proposed reform, most of the students agreed with the change and would prefer to write a research paper than to be tested on knowledge, and most reported that they would have been capable of writing such a paper in high school. The distribution of the respondents' attitudes is presented in Figure 4.

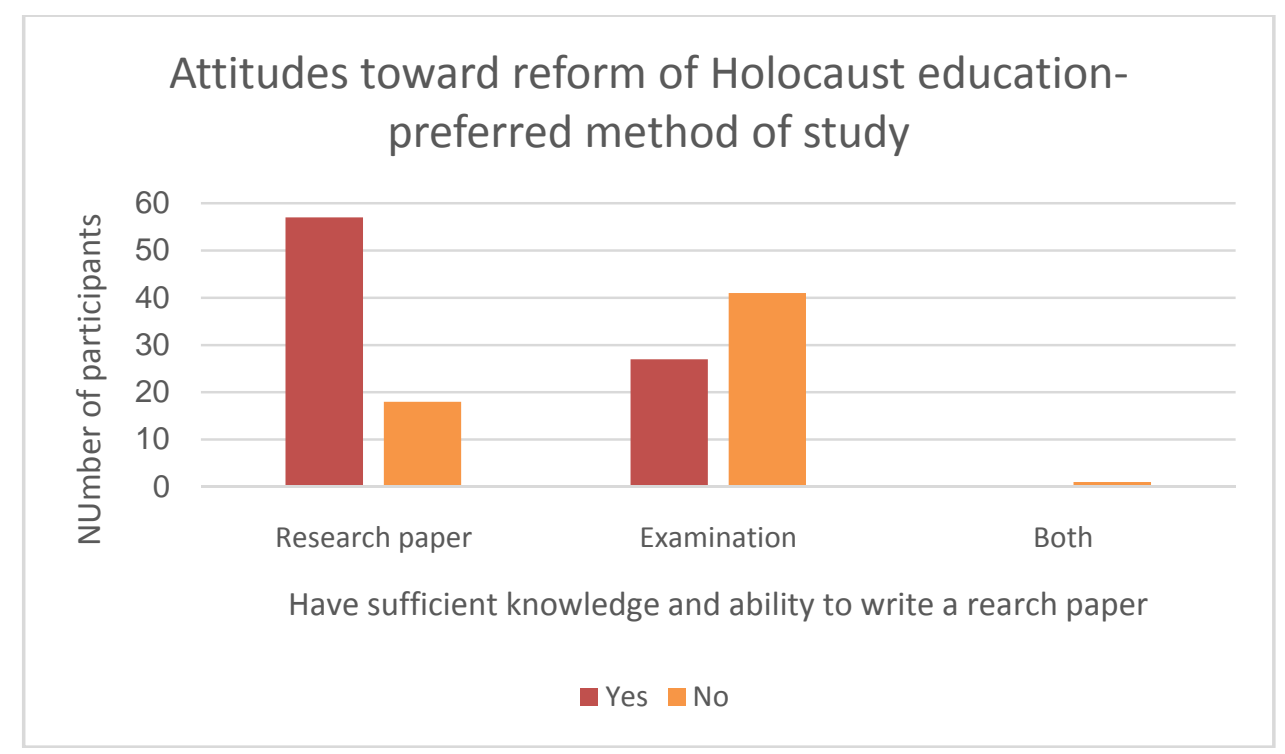

Fig. 4. Attitudes toward reform of Holocaust education-preferred method of study.

Finally, we shall present the level of knowledge by question.

Table 2

Distribution of Terms by Number and Percentage of Correct Responses

\begin{tabular}{llll}
\hline No. & Term & Number of correct responses & Percentage of correct responses \\
\hline 1 & Righteous among the nations & 126 & $87 \%$ \\
2 & Death pits & 123 & $85 \%$ \\
3 & 3 countries in which the Holocaust took place & 118 & $81 \%$ \\
4 & Kristallnacht & 116 & $80 \%$ \\
5 & Concentration camp & 113 & $77 \%$ \\
6 & Zyklon b & 111 & $76.5 \%$ \\
7 & "Final solution" & 110 & $76 \%$ \\
8 & Nuremberg laws & 76 & $52 \%$ \\
9 & State the name of 3 death camps & 61 & $42 \%$ \\
10 & Mordechai Anielewicz & 51 & $35 \%$ \\
11 & Judenratt & 35 & $24 \%$ \\
12 & Eichmann & 32 & $22 \%$ \\
13 & Camps for the displaced & 30 & $21 \%$ \\
14 & Nuremberg trials & 30 & $21 \%$ \\
15 & Sonderkommando & 27 & $19 \%$ \\
16 & ŻOB, ŻZW & 23 & $16 \%$ \\
17 & Himmler & 19 & $13 \%$ \\
18 & The Kastner Affair & 16 & $11 \%$ \\
19 & Einsatzgruppen & 10 & $7 \%$ \\
20 & Operation Reinhard & 4 & $3 \%$ \\
\hline
\end{tabular}




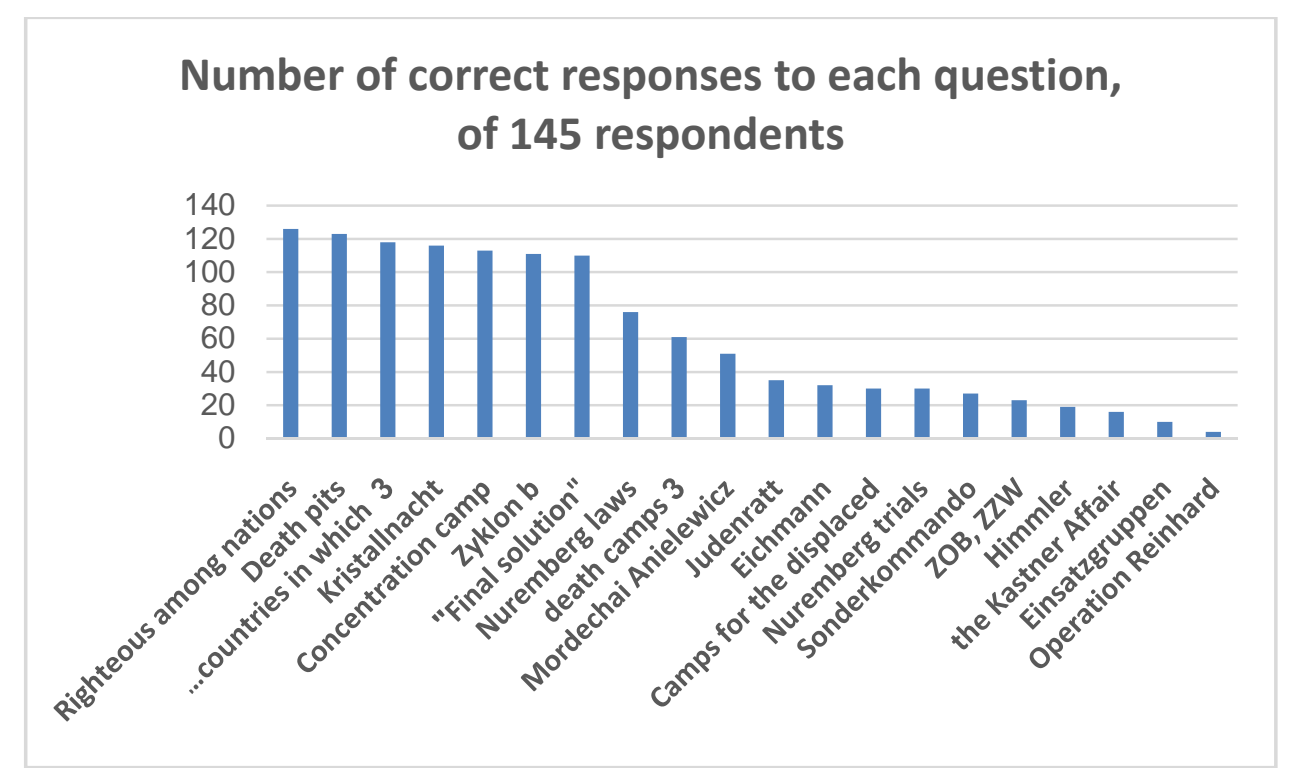

It is evident that the more familiar terms were those for whom the answer was contained in the definition of the term, for example: Righteous among the Nations, death pits, concentration camps, "Final solution," or very basic terms in the history of the Holocaust, such as: State three countries that were locations of the Holocaust (where most respondents stated Germany and Poland and a third country) or Zyklon b. On other terms, there is a significant drop in the level of knowledge, including terms that could have been expected to be more well known, such as the names of death camps (most of those who responded identified Auschwitz and Birkenau and a third camp), Mordechai Anielewicz, Eichmann, and Himmler.

\section{Conclusion and Discussion}

In the theoretical part of the study we pointed to the evolvement of Holocaust studies in the school system, the differences between disparate institutions and religious streams, and the differences between formal and informal studies.

Landmarks in Holocaust studies:

- In 1981, the Knesset enacted the amendment to the State Education Law of 1953, which determined the obligation to teach about the Holocaust in the school system;

- The Holocaust is taught today as part of history studies in the ninth and eleventh grades;

- Beginning from the 1980s, some eleventh and twelfth graders have been going on a journey to Poland. An inseparable part of Holocaust studies is a visit to one of the Holocaust institutes throughout Israel;

- In March 2010, the Minister of Education at the time, Gideon Sa'ar, decided that all eleventh graders would be obligated to take part in preparatory days for the journey to Poland, even if they do not take part in the journey itself;

- In April 2014, the Minister of Education, Rabbi Shai Piron, decided that Holocaust studies would begin in kindergarten;

- Beginning from 1951, the State of Israel has marked Holocaust and Heroism Remembrance Day on 27 Nissan. Remembrance Day is marked by official ceremonies. On Remembrance Day eve and on the day itself, the media broadcasts programs, survivor testimonies, and films about the Holocaust. On Holocaust 
Remembrance Day, schools hold ceremonies and the day is dedicated to encounters with Holocaust survivors and academic activities on the subject;

- In 2005, the UN decided to designate January 27, the day on which Auschwitz was liberated by the Red Army, as International Holocaust Remembrance Day. On this day as well, the electronic and printed media dedicates extensive coverage to the topic of the Holocaust;

- In religious and ultra-Orthodox sectors, Holocaust Remembrance Day is marked on 10 Tevet;

- The topic of the Holocaust is increasingly receiving a great deal of exposure in political contexts;

- The Holocaust is a major component of Israeli identity. Moreover and as presented, it is apparent that the Holocaust receives extensive formal and informal exposure. Hence, a worthy subject of inquiry would be what information high school graduates retain.

Efforts made over the years to preserve and impart memories and in light of the reform proposed whereby high school students will no longer be tested on the Holocaust as part of the matriculation exam in history and will be required to write a research paper instead (http://www.nrg.co.il/online/1/ART2/735/464.html).

In this study, we examined the knowledge retained by high school graduates who are students at academic institutions throughout Israel, about the Holocaust. We also wished to explore the students' personal background (sex, age, religiosity, schooling, participation in the journey to Poland, family ties to Holocaust survivors or victims, and visits to a Holocaust institute) and its effect on their knowledge.

The following are the research findings in the empirical part, surprising findings, common errors, and what people remember:

- $23(15.7 \%)$ respondents could not state even one name of a death camp;

- $19(13 \%)$ respondents mentioned Warsaw or the Warsaw Ghetto as a death camp;

- The Judenratt was identified as the Jewish police and as collaborators with the Nazis;

- With regard to Adolf Eichmann, many of the respondents did not know his role in the "Final Solution" but knew that he was caught in Argentina, put on trial in Israel, and executed by hanging;

- Many referred to Heinrich Himmler as responsible for propaganda in Nazi Germany (confused him with Goebbels);

- Many stated that Kastner betrayed Jews to save his family;

- The Chelmno and Belzec death camps are not well known (one respondent mentioned Chelmno and one Belzec in the list of death camps).

Respondents' sources of information: The school appears to fill a significant role as students' main perceived source of knowledge, where 68 (46.6\%) respondents referred to it as the only source of knowledge, and $64(43.8 \%)$ noted the school as their major source of knowledge, together with other sources. Hence, 132 (90.4\%) respondents referred to the school as their major or additional source of knowledge. One respondent did not answer this question.

With regard to the future, when asked about the new format, most of the students $(52.1 \%)$ answered that they would prefer to write a research paper over being tested, and most (57.5\%) also answered that they would have been capable of writing a research paper with all this entailed while in high school. One of the respondents did not answer these two questions.

The Holocaust is a major component of Israeli identity. The Holocaust chapter is a focus of history studies, journeys to Poland, visits to Holocaust institutes, ceremonies, annual remembrance days, films, and books. 
The study found a low level of knowledge among the population of undergraduate students. Assumedly, the level of knowledge among a similar population that did not meet the threshold conditions for admission to the various academic institutions would have been identical or even lower.

In an era when Holocaust survivors are reaching the age when they are gradually departing from this world, concerns are often voiced as to future remembrance of the Holocaust. The findings of the current study show that these concerns are not misplaced.

\section{Recommendations}

The study indicates the school as a major source of information about the Holocaust. In view of the low level of knowledge found in the study, several important questions are indicated:

- Do the schools teach adequately?

- Should the study program be reexamined?

- Are we providing the proper emphases?

- What is the contribution of the journey to Poland? (38 respondents $(60 \%)$ of those who were in Poland have no knowledge of Mordechai Anielewicz! During the journey, students visit Mila 18, hold a ceremony near the Ghetto Heroes' Monument, read aloud Anielewicz's "last letter" in many ceremonies.)

- What can be done to improve the situation?

- Will the decision not to include the Holocaust in the material for the matriculation exam in history and to require students to write a research paper to improve the situation?

- What is the future of remembrance in a time when Holocaust survivors will no longer be around to tell their story?

We recommend that a study be conducted with a wider population of students in order to examine the validity of the findings.

In addition, we recommend examining the differences in Holocaust studies between institutions of different religiosity and whether it is possible to discern what causes differences in knowledge. Moreover, it is necessary to examine the significance of the school as the major source of knowledge and how teaching can be improved so that knowledge will be preserved. Informal teaching, including the trip to Poland, may have a significant role, and it should be used more often.

Furthermore, despite students' support of the reform and their belief that a research paper is preferable to taking an exam on the Holocaust, it is necessary to examine what the research paper includes and whether writing a paper on a certain topic related to the Holocaust will not create a situation where students know nothing else about the Holocaust but that specific subject. In addition, it is necessary to relate to students' ability to write a research paper. Students indeed answered that they would have been capable of writing such a paper, but the question is whether high school students are indeed capable of this and whether they have all the necessary knowledge and tools.

\section{Works Cited}

Amendment to the State Education Law of 1953.

Balf, M. "Holocaust Survivors on Kibbutzim." Eds. D. Ofer, F. S. Ouzan, and J. T. Baumel-Schwartz. Holocaust Survivors: Resettlement, Memories, Identities 32.3 (2011): 146-8. New-York: Berghahn Books. 
Davidovitch, N. "Man-God Discourse: The Place of Faith in Holocaust Studies." Eds. N. Davidovitch and D. Soen. The Valley of the Shadow of Death: The Holocaust Experience from a Multidisciplinary Perspective. Ariel: Resling, 2015. 237-64. Hebrew.

Davidovitch, N. and Soen, D. "Youth Journeys to Poland: Pros and Cons." Holocaust Remembrance: Issues and Challenges. Ariel: Ariel University Center of Samaria, 2011. 76-99. Hebrew.

---. "Holocaust and Experience: On Experiential Studies on the Holocaust." Holocaust Remembrance: Issues and Challenges. Ariel: Ariel University Center of Samaria, 2015a. 316-30. Hebrew.

---. "Does the Path to Jewish Identity and to Contact with Diaspora Jewry Pass through Remembrance of the Holocaust?" The Valley of the Shadow of Death: The Holocaust Experience from a Multidisciplinary Perspective. Ariel: Resling, $2015 \mathrm{~b}$. 175-96. Hebrew. 